\section{A Shrew Report}

by Donna Anderson, age 11, Coderre, Sask.

Our teacher takes the Blue Jay magazine. She often reads articles out of it. Today she happened to find a shrew, a tiny little fellow. Its body is about one inch and half long, its tail is about one inch. We were able to identify the shrew from the "Book of Knowledge." This is the second shrew that has been found in the school yard. Our school, Wood Valley No. 4441, is four miles south of Coderre, near Wood River.

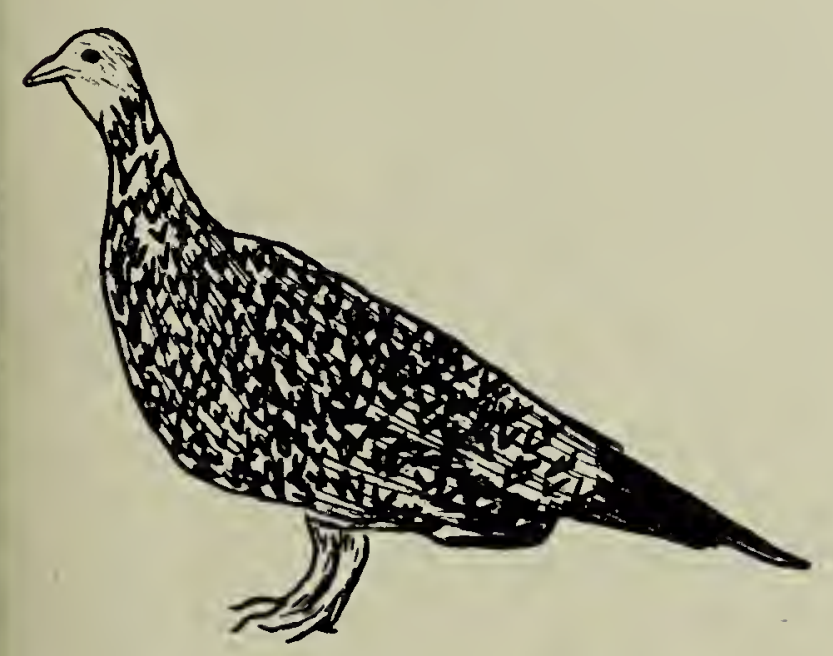

SHARP-TAILED GROUSE

by Dan Pawlivisky, age 10, Square Hill, Sask.

\section{A Squirrel's Nest}

by Kenneth Howland, age 12 , Adams, Sask.

About two years ago my brother and I found a squirrel's nesit. We were walking in the valley and a red squirrel ran out of an old crow's nest and started scolding us. I climbed up the tree and looked at the nest. The squirrel had chewed bark and put it in the crow's nest. Inside the nest there were four little pink squirrels. All the time I was looking at the nest the mother squirrel was running around the trees scolding me.

When we got up to the house we decided to phone and tell Doug Gilroy. When Doug came over to look at the baby squirrels they were gone. The mother must have moved them to another place after we had discovered them. It was too bad he missed them but there's always another time.

NOTE: Doug Gilroy writes a weekly nature column in the Western Producer.

\section{A Surprise Visitor}

by Joan Anderson, Age 12, Coderre, Sask.

One lovely autumn day, when the soft fleecy clouds were floating in the sky, the autumn leaves swirling to the ground, we had a visitor.

The day was really too nice to be in school especially when the Nurse was here with her needles!

The school door stood open to let the sushine in. All at once we heard a flutter and a chirp out on the porch, it announced the entrance of a tiny bird. He settled himself on the school globe. We children said he was looking at the globe to see were he was going to spend the winter!

In a minute we were all excited. We closed the door, captured our frightened visitor with the butterfly catcher, made of a coat hanger and mosquito netting. Poor little fellow, we could feel his little heart pounding. We got out our bird book and identified him as a Redbreasted Nuthatch. We wished him good luck, took him to the door and away he flew.

\section{Strange Noise}

by Garry Thompson, Age 15

Rokeby, Sask.

When I was five or six or maybe older I heard a noise in the morning and early at night. It was like Indians playing their war drums, but it would stop and start. I would run in the house and tell them of the strange noise I heard and they would say. "You are hearing things." That's the way it was for a few years.

One night when I was twelve years old, I was taking the cows home. I heard that same noise very close to me. I walked up closer to find it and I saw six Ruffled Grouse with all their black feathers ruffed out around their neck. Their wings were down and their tails all spread out. They were making the drumming sound by filling up their wind bags in their throat and letting the air out, and dancing on the hard cow path.

NOTE: It is not surprising that the noise Garry heard resembled the rhythm of Indian drums. The Plains Indians would imitate the dance of the grouse. As part of their dancing 
costume they would wear a "tail" using grouse feathers in its construction. Their dancing would imitate the dance of the grouse.

Some of the details in Garry's report are a bit cofused, which can perhaps be explained by the fact that he reported something he saw several years ago. There are seven species of grouse in Saskatchewan, each with a distinctive mating dance.

The Ruffed Grouse dances alone, choosing as a rule a hollow log. Here he "drums" by rapidly beating the air with his wings. The Ruffed Grouse does not have the air sacs that some of the other grouse have, but does have a ruff of feathers from which it gets its name.

The Sharp-tailed Grouse usually dances in groups. They have air sacs which pump air in and out.

NOTE: The booklet "Sharp-tailed Grouse in Saskatchewan," which is reviewed on page 185 , can be obtained by writing:

Conservation and Information Service, Department of Natural Resources,

Regina, Saskatchewan.

\section{Small But Scary}

by Gerald Kreba, Rokeby, Sask.

One day Dad told me and my brother David to go down the power line and look for fence posts. The power line is a place with lots of bush near our place. As we were walking along we heard a loud screeching noise. We fell to the ground and listened. Then it came again. We decided to get a look at it. I thought it might be a bear, but. David said, "Don't be silly."

As we were sneaking along we saw a small bird sitting on a branch. It was smaller than a grouse. David said it was a small grouse but we decided differently when it looked at us. The bird's eyes were like marbles. In its mouth it held a struggling mouse. He was so busy with the mouse we got real close and had a good look at it. I thought it was a kind of owl. When we got home we looked at some pictures and found thait our scary friend was a Screech Owl.

NOTE: The Screech Owl is one of our smaller owls and is found in the southern part of the province. Its diet consists almost entirely of small rodents-mice, rats, ground squirrelsand is therefore considered beneficial.

\section{Wish}

By Helen Furtan and Elenor Konechny, White Rose School, Kegworth)

I wish:

I could sing like the meadowlark in the show.

I could pick a husibland like the Wilson's Phalarope to look after the children so I could go and visit the museum every day when I grow up.

I could run like an antelope.

I could tish like a pelican.

I had a windpipe as long as the Trumpeter Swan to call with.

I was as pretty as the Trumpeter Swan.

I had ears as long as the southern Jack rabbit so I could hear better.

We could all live in towns like the prairie dogs.

The boy sage hens' wouldn't strut around like that.

I had perfume like the sage brush.

I had long legs like the deer to jump with.

I was a porcupine with all those quills to stick somebody when I'm cross.

I was a skunk, so if boys come around me I could skunk them.

I was a buffalo to have a thick fur coat.

But I'm glad:

I'm not a snake having one meal in two weeks.

I'm not a cowbird eating ticks and lice off the buffalo.

I'm not a father Wilson's Phalarope and have to watch the baby birds alone.

That I went to the Saskaitchewan Museum.

EDITOR'S NOTE: This poem was inspired by a tour of the Museum made by the pupils of White Rose School. Guided tours are a regular part of the Museum's extension program. For information and application forms write to:

Extension Officer,

Sask Museum of Natural History, Regina, Saskatclıewan. 